\title{
INHIBITION OF FIBRIN POLYMERIZATION BY SYNTHETIC PEPTIDES CORRESPONDING TO Aa195-205 AND $\gamma$ 69-77 SITES OF FIBRIN MOLECULE
}

\author{
T. A. POZNIAK, L. P. URVANT, P. G. GRITSENKO, V. I. CHERNISHOV, \\ N. A. PYDIURA, E. V. LUGOVSKOI, S. V. KOMISARENKO \\ Palladin Institute of Biochemistry, National Academy of Sciences of Ukraine, Kyiv; \\ e-mail: lougovskoy@yahoo.com
}

\begin{abstract}
Using the idea of "proline brackets" we have found four sites in fibrin amino acid sequence, and appropriate peptides were synthesized: $\gamma 69 N P D E S S K P N 77, B \beta 228 Q P D S S V K P Y 236, B \beta 455 R P F F P Q 460$ and Aa195LPSRDRQHLPL205. Turbidity and electron-microscopy analyses have demonstrated that synthetic peptide Aa195-205 specifically inhibited the stage of fibrin protofibril formation and peptide $\gamma 69-77$ - the stage of fibrin protofibril lateral association. The data obtained testify that there are the sites involved in these processes in the appropriate amino acid sequences of fibrin molecule.
\end{abstract}

Key words: sites of fibrin polymerization, peptides, inhibitors, proline brackets.

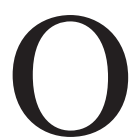

$\mathrm{n}$ activation of the blood coagulation system thrombin is formed. This enzyme cleaves two fibrinopeptides A (FpA) from fibrinogen and transforms it into fibrin desA which is able to polymerize spontaneously by the intermolecular pairing of the complementary polymerization sites "A" and "a" $[1,2]$. As a result, the two-thread protofibrils are formed (the first step of polymerization), which associate laterally (the second step of polymerization), branch out and form the three-dimensional framework of thrombus [3]. After protofibril formation thrombin cleaves fibrinopeptides $\mathrm{B}(\mathrm{FpB})$ from fibrin desA, accelerating protofibrils lateral association.

There are data testifying to the existence of other functional sites participating in the fibrin polymerization process. Localization and elucidation of a functional role of these sites give a possibility to choose some of them for the synthesis of low-molecular weight peptides, which prevent the formation of three-dimensional fibrin network and thrombus creation.

The aim of this work is the localization of fibrin unknown functional sites, which participate in the process of its polymerization.

Identification of protein-protein interactions sites is one of the most complicated tasks in proteins chemistry. It has been known from the literature that two residues of proline, which are located at the distance of approximately 3-7 amino acid residues in a protein molecule, create so-called "proline brackets" and often encompass the sites of inter-protein interaction [4]. A destruction of $\alpha$-coil and a protein chain bend are observed in such a site. Thus, proline residues, perhaps, play a structural role, giving some conformation necessary for proteins interaction, to the sites they limit $[5,6]$. Correspondingly, the sites of protein-protein interactions may be predicted in the presence of "proline brackets" [7]. Basing on such approach, Budzynski et al. [8] have presumed existence of fibrin polymerization site in the amino acid sequence Aa541-574, where the "proline bracket" is located (A $\alpha 546-552)$. We have earlier localized the site of the fibrin polymerization in the fragment B326APSLRPAPPPISGGGYRARPA46 [9].

We have applied such approach in this work to preliminary localization of functionally important sites of fibrin molecule.

\section{Matherials and Methods}

Human fibrinogen was isolated from human blood plasma by fractional salting out with natrium sulphate [10]. Fibrin desA [11] and fibrin desAB [12] were obtained in fibrinogen+thrombin reaction.

Turbidity analysis of fibrin polymerization. The effects of synthetic peptides at various concentrations on fibrin polymerization were studied spectrophotometrically at $350 \mathrm{~nm}$. Polymerization of fibrin desA and desAB was studied at a final concentration $0.1 \mathrm{mg} / \mathrm{mL}$ in the polymerization medium containing 
$0.05 \mathrm{M}$ ammonium acetate ( $\mathrm{pH}$ 7.4) with $0.1 \mathrm{M} \mathrm{NaCl}$ and $10^{-4} \mathrm{M} \mathrm{CaCl}_{2}$. Polymerization of fibrin formed in the fibrinogen + thrombin reaction was investigated at a final concentration of fibrinogen of $0.1 \mathrm{mg} / \mathrm{mL}$ and a final concentration of thrombin of $0.4 \mathrm{NIH}$ units/ $\mathrm{mL}$ in the same polymerization medium. The curve of increasing turbidity during fibrin clotting shows the following parameters: $\tau$, the lag-time, which corresponds to the time of protofibril formation; $V_{\max }$, maximum rate of fibrin polymerization, which was defined by graphic calculation of the angle of the tangent to the turbidity increase curve at the point of maximum steepness; and $\Delta \mathrm{h}$, final turbidity of fibrin clots.

Electron microscopy. The samples of polymerizing fibrin desAB in the absence or presence of synthetic peptides A $\alpha 195-205$ or $\gamma 69-77$ were taken out of the reaction medium at various times, placed on a carbon-coated grid for $2 \mathrm{~min}$, and then stained with $1 \%(\mathrm{w} / \mathrm{v})$ uranyl acetate (Merck, Germany) for 1 min. Transmission electron microscopy was performed in a H-600 electron microscope (Hitachi, Chiyoda, Japan) operated at $75 \mathrm{kV}$. Electron micrographs were obtained at a magnification of 50000 on Kodak SO-163 film.

Statistical analysis of the received data has been conducted by usage of software Prism 5 (GraphPad Software Inc., USA). To determine connection between studied definitions, Pirson correlation coefficients (characterize measure of linear relation between variables) have been used, validity has been estimates in compliance with Student's $t$-criterium. Maximal rate of polymerization $\left(V_{\max }=\left(\mathrm{dE}_{350} / \mathrm{dt}\right)_{\mathrm{t}=\tau}\right.$, where $\tau$ - lag-period $)$ has been determined by graphic differentiation of turbidity curve (tangent of pitch angle to the most steep initial section of light dispersion ).

\section{Results and Discussions}

Amino acid sequences of fibrin $\alpha-, \beta$ and $\gamma$-chains involving "proline brackets": $\gamma 69$ NPDESSKPN77, B $\beta 228$ QPDSSVKPY236, B $3455 R P F F P Q 460$ and A $\alpha 195$ LPSRDRQHLPL205 were chosen. Corresponding peptides were synthesized using solid-phase method (State Scientific Center "Institute of Immunology" of Federal Medical-Biology Agency of Russia) and their influence on fibrin polymerization was studied by turbidity analysis.

We found that two synthetic peptides, imitating the $\beta$-chain fragments of fibrin(ogen) $B \beta 228-236$, $\mathrm{B} \beta 455-460$, did not affect the process of fibrin polymerization. Thus, do not all sites which structurally correspond to "proline brackets" and are involved into intermolecular associations of fibrin. These peptides have been used as a negative control.

The synthetic peptides, which imitate the fibrin(ogen) amino acid sequences A 195-205 and r69-77, specifically inhibit the process of fibrin polymerization.

Fig. 1 shows that synthetic peptide A $\alpha 195-205$ significantly decreases maximal rate of fibrin polymerization, prolongs the time of protofibrils formation and does not practically change the final turbidity of the clot. The peptide concentration under which the maximal rate of the fibrin polymerization decreases two times $\left(\mathrm{IC}_{50}\right)$ was equal $2.38 \cdot 10^{-4} \mathrm{M}$ at the molar ratio of the protein to the peptide $1: 800$. a

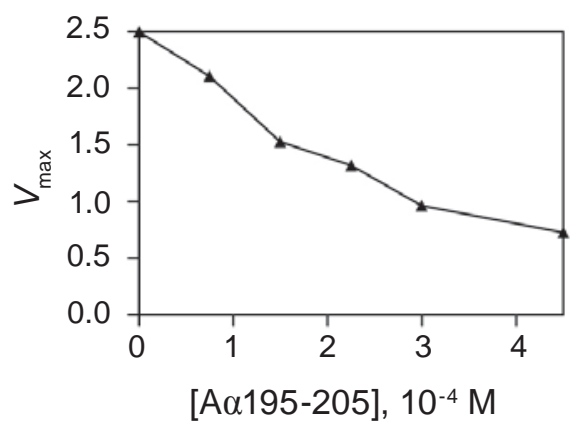

$b$

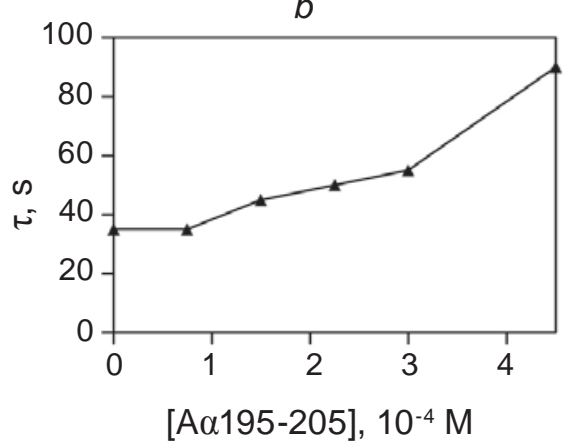

C

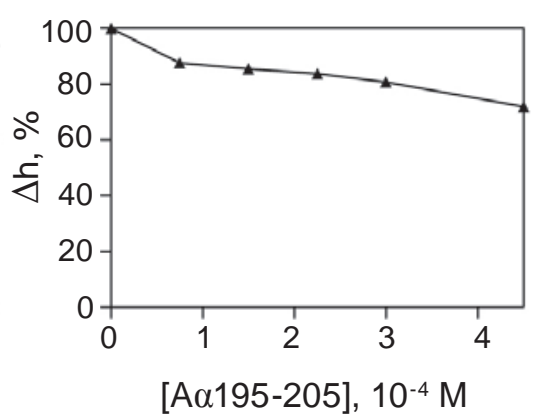

Fig. 1. The influence of the synthetic peptide Aa195-205 on polymerization of fibrin produced in fibrinogen+thrombin reaction in turbidity analysis. The dependence of the maximal rate of the fibrin polymerization (a), the lag time (b), and final turbidity of fibrin clots (c) on concentration of Aa195-205. The figure shows typical shapes of the curves illustrating the dependence of three parameters of fibrin polymerization on peptide concentration 
Peptide Aa195-205 inhibits polymerization of monomeric fibrins desA and desAB as well. $\mathrm{IC}_{50}$ value for fibrin desA polymerization is $1.34 \cdot 10^{-4} \mathrm{M}$ at molar ratio of the fibrin to the peptide $1: 400$ and $2.2 \cdot 10^{-4} \mathrm{M}-$ for fibrin desAB, that coincides with $\mathrm{IC}_{50}$ for fibrinogen+thrombin system. Thus, the inhibitory effect of the peptide is related to the process of the fibrin polymerization but not to the enzymatic step of fibrinogen to fibrin transformation.

To answer the question which stage of polymerization is inhibited by peptide Aa195-205, electron-microscopy study has been performed.
Transmission electron microscopy showed that peptide Aa195-205 inhibits the first stage of fibrin polymerization - protofibrils formation out of fibrinmonomers. It has been demonstrated that while in the absence of Aa195-205 peptide only cross-striated fibrils are observed, only fibrin oligomers are observed in the presence of the peptide (Fig. 2).

Thus, results of the turbidity and electron-microscopy studies demonstrate that synthetic peptide, which imitates amino acid sequence Aa195-205 of fibrin molecule, inhibits the first stage of the fibrin polymerization - protofibrils formation. Thus, we
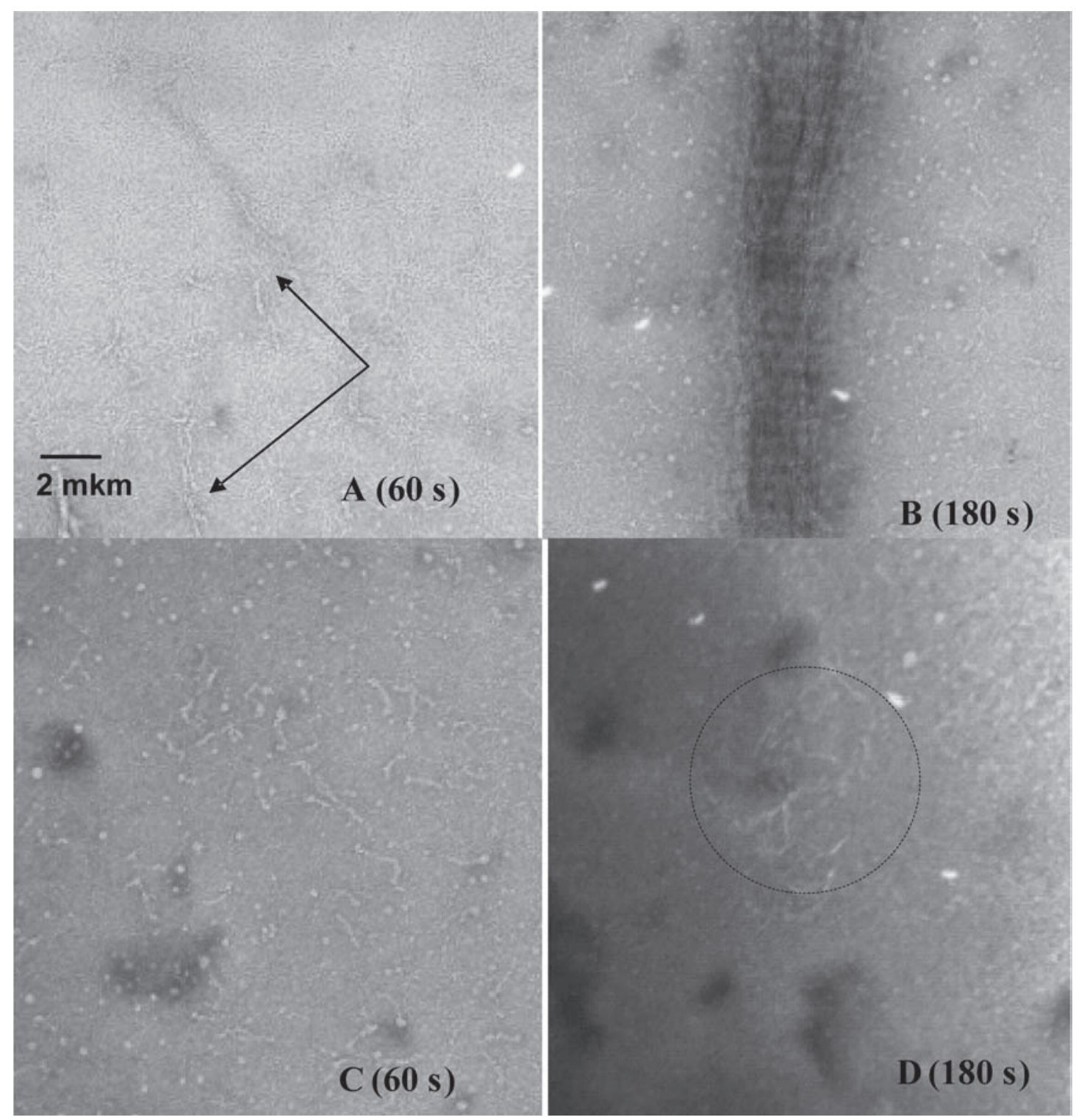

Fig. 2. Electron micrographs of negatively contrasted structure formed during polymerization of fibrin produced in fibrinogen+thrombin reaction in the absence $(A, B)$ and in the presence $(C, D)$ of synthetic peptide Aa195-205 in 60s and 180s from start of the reaction 
may presume that fibrin site Aa195-205 is involved in the process of protofibrils formation.

An analysis of fibrin(ogen) amino acid se-

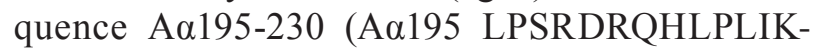
MKPVPDLVPGNFKSQLQKVPPEWK230) has demonstrated the existence of the significant quantity of proline residues and thus so called "proline brackets" [4]. This indicates non-structuring of this portion of fibrin(ogen) molecule and its increased ability to inter-protein connections. It is known that recombinant fibrinogen, $\alpha$-chain of which consists of Aa1-251 amino acid residues, is polymerized by thrombin almost with the same rate as native fibrinogen [14]. This fact and the inhibition of the intermolecular interaction of fibrin monomers by peptide A 195-205 allows us to presume that there is a site in this section of fibrin molecule, which participates in the fibrin protofibrils formation. Thus, the inhibitory action of synthetic peptide Aa195-205 may be explained by the competitive inhibiting of interaction of the A $195-205$ site in fibrin molecule with a complementary site during intermolecular interaction of fibrin-monomers.

Turbidity analysis showed a more pronounced inhibitory effect of synthetic peptide $\gamma 69$ 77 on fibrin polymerization. $\mathrm{IC}_{50}$ in the system of fibrinogen+thrombin was $1.5 \cdot 10^{-5} \mathrm{M}$ at molar ratio of protein to peptide $1: 50$, that testifies to the high specificity of the effect (Fig. 3). As concentration of the peptide increases, its inhibitory action increases. This fact proves competitive type of inhibition. This permits us to suggest that fibrin site $\gamma 69-77$ is involved in the fibrin polymerization process.

Synthetic peptide $\gamma 69-77$ also inhibits polymerization of fibrins des $\mathrm{A}$ and des $\mathrm{AB}$ monomers. $\mathrm{IC}_{50}$ value for fibrin desA is a $1.25 \cdot 10^{-4}$ and $0.5 \cdot 10^{-4} \mathrm{M}-$ for fibrin desAB. Thus the inhibition action of the peptide $\gamma 69-77$ concerns the process of fibrin polymerization, but not the step of fibrinogen into fibrin transformation by thrombin.

Transmission electron microscopy showed that peptide $\gamma 69-77$ inhibits the second step of fibrin polymerization - the protofibrils lateral association. Fig. 4 shows that mature fibrils were observed in the absence of peptide, but in the presence of $\gamma 69-77$ only separate protofibrils were observed.

Amino acid sequence $\gamma 69-77$ is the structural component of the part of the coiled-coil connector, which binds the central and the peripheral regions of fibrin(ogen). In this part of the coiled-coil $\gamma 69$ $77 \alpha$-coil interacts with B $\beta 126-135$ and A $\alpha 91-103$ $\alpha$-coils. A possible reason of inhibiting effect of the synthetic peptide $\gamma 69-77$ is its competitive interaction with A $\alpha 91-103$ and B $\beta 126-135$ constituents, and, as a result - disturbance of the whole structure in this part of coiled-coil. Synthetic peptide B $\beta 121$ 138 which includes the site B $3126-135$ also inhibits protofibrils lateral association [15]. Such competitive mechanism of inhibition was proposed earlier by Jing et al. for the synthetic peptide, which imitates fibrinogen amino acid sequence $\gamma 23-57$, which belongs to the coiled-coil region of fibrin(ogen) molecule [16].

Thus, two new functional sites A $\alpha 195-205$ and 769-77 have been localized in fibrinogen molecule. The former is involved in the process of protofibrils formation, and the latter - in the protofibrils lateral association. Interestingly that the sequence $\gamma 69-77$ involves peptide bond $\gamma 72-73$ which is cleaved by plasmin. The cleavage of this bond decreases ob- a

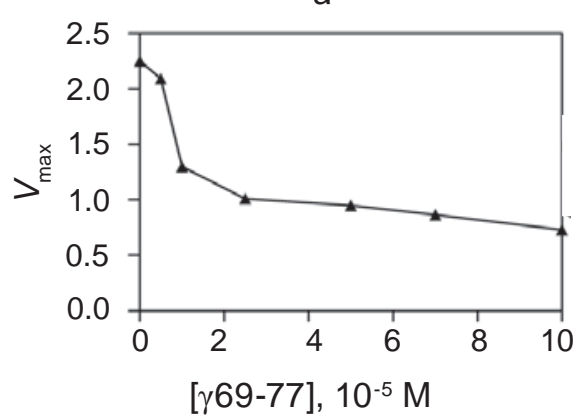

$b$

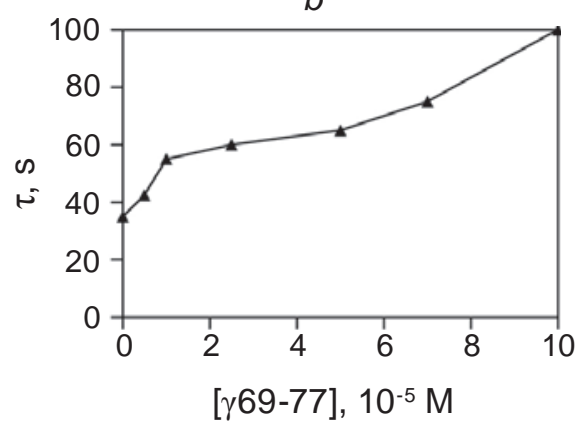

C

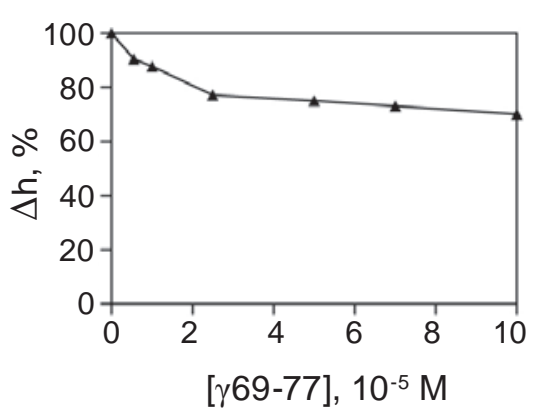

Fig. 3. The influence of the synthetic peptide $\gamma 69-77$ on polymerization of fibrin produced in fibrinogen + thrombin reaction in turbidity analysis. The dependence of the maximal rate of the fibrin polymerization (a), the lag time (b), and final turbidity of fibrin clots (c) on concentration of $\gamma 69-77$. The figure shows typical shapes of the curves illustrating the dependence of three parameters of fibrin polymerization on peptide concentration 

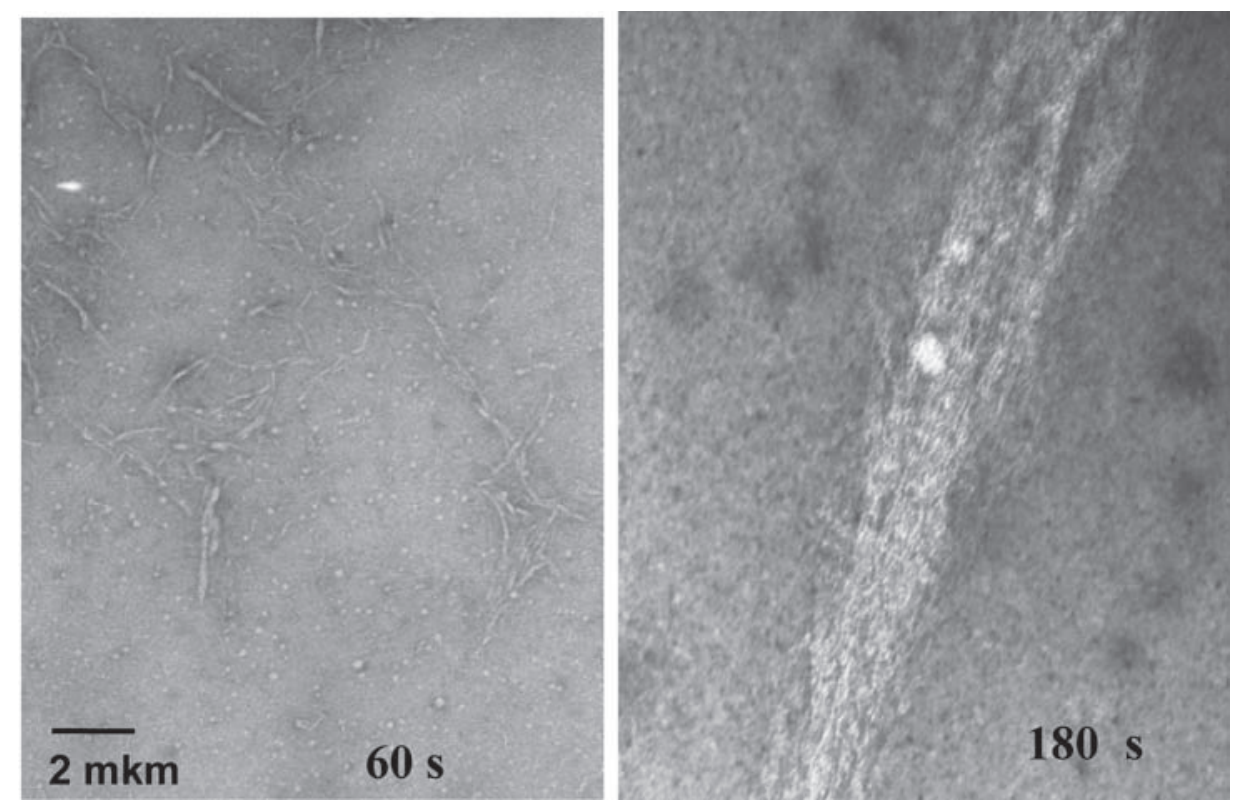

Fig. 4. Electron micrographs of negatively contrasted structure formed during polymerization of fibrin produced in fibrinogen +thrombin reaction in the presence of synthetic peptide g69-77 in $60 \mathrm{~s}$ and $180 \mathrm{~s}$ from the reaction start

viously the interprotofibrils contacts and promotes quick destruction of the final fibrin clot by plasmin.

It is known that proline amino acid residues which encompass sites of interprotein interactions form a stable structure in such regions of the molecule by decreasing of the number of possible conformations. Obviously, the stabilization of the structure by "proline brackets" provides a high affinity of protein-protein interactions [6]. Thus, encompassing of a biologically active synthetic peptide by proline residues can significantly increase its physiological activity. The approach may be useful for the design of peptide medicines. Allowing for the high inhibitory activity of the synthetic peptide $\gamma 69-77$ $\left(\mathrm{IC}_{50}=1.5 \cdot 10^{-5} \mathrm{M}\right)$, it may be the basis for the creation of a new antithrombotic medicine.

Authors of this work are grateful to Yevgen Makogonenko for fruitful discussion of the results. 


\section{ІНГІБУВАННЯ ПОЛІМЕРИЗАЦІЇ ФІБРИНУ СИНТЕТИЧНИМИ ПЕПТИДАМИ, ЯКІ ВІДПОВІДАЮТЬ ДІЛЯНКАМ А $\alpha 195-205$ I $\gamma$ 69-77 МОЛЕКУЛИ ФІБРИНУ}

Т. А. Позняк, Л. П. Урвант, П. Г. Гриценко,

B. I. Чернишов, М. О. Пидюра,

Е. В. Луговськой, С. В. Комісаренко

\author{
Інститут біохімії ім. О. В. Палладіна \\ НАН України, Київ; \\ e-mail: lougovskoy@yahoo.com
}

За використання принципу «пролінових скоб» в амінокислотній послідовності фібрину виявлено чотири ділянки та синтезовано відповідні їм пептиди: $\gamma 69$ NPDESSKPN77, Bß228QPDSSVKPY236, B $3455 R$ PFFPQ460 та Ad195LPSRDRQHLPL205. Методами турбідиметричного аналізу та електронної мікроскопії показано, що синтетичний пептид А 195-205 специфічно інгібує стадію формування протофібрил фібрину, а пептид ү69-77 - стадію латеральної асоціації протофібрил. Одержані результати дозволяють припустити, що в досліджуваних амінокислотних послідовностях фібрину розташовані сайти, які беруть участь у процесах полімеризації.

К л ю ч о в і с л о в а: сайти полімеризації фібрину, пептиди, інгібітори, пролінові скоби.

\section{ИНГИБИРОВАНИЕ ПОЛИМЕРИЗАЦИИ ФИБРИНА СИНТЕТИЧЕСКИМИ ПЕПТИДАМИ, СООТВЕТСТВУЮЩИМИ УЧАСТКАМ Аа195-205 И ү69-77 МОЛЕКУЛЫ ФИБРИНА}

Т. А. Позняк, Л. П. Урвант, П. Г. Гриценко,

В. И. Чернышов, М. А. Пьдюра,

Э. В. Луговской, С. В. Комисаренко

\author{
Институт биохимии им. А. В. Палладина \\ НАН Украины, Киев; \\ e-mail: lougovskoy@yahoo.com
}

При использовании принципа «пролиновых скобок» в аминокислотной последовательности фибрина обнаружено четыре участка и синтезировано соответствующие им пептиды: $\gamma 69$ NPDESSKPN77, B $3228 Q P D S S V K P Y 236$, Bß455RPFFPQ460 и A $\alpha 195 L P S R D R Q H L P L 205$.
Методами турбидиметрического анализа и электронной микроскопии показано, что синтетический пептид А $\alpha 195-205$ специфически ингибирует стадию формирования протофибрилл фибрина, а пептид ү69-77 - стадию латеральной ассоциации протофибрилл. Полученные результаты позволяют предположить, что в исследуемых аминокислотних последовательностях фибрина расположены сайты, принимающие участие в процессах полимеризации.

Кл ю че вы е с лов в: сайты полимеризации фибрина, пептиды, ингибиторы, пролиновые скобки.

1. Averett L. E., Schoenfisch M. H., Akhremitchev B. B., Gorkun O. V. Kinetics of the multistep rupture of fibrin 'A-a' polymerization interactions measured using atomic force microscopy // Biophys. J. - 2009. - 97, N 10. - P. 2820-2828.

2. Fowler W. E., Hantgan R. R., Hermans J., Erickson H. P. Structure of the fibrin protofibril // Proc. Nat. Acad. Sci. USA. - 1981. - 78, N 8. P. 4872-4876.

3. Weisel J. W., Veklich Y., Gorkun O. The sequence of clevage of fibrinopeptides from fibrinogen is important for protofibril formation and enhancement of lateral agregation in fibrin clots // J. Molec. Biol. - 1993. - 232, N 1. - P. 285-297.

4. Kini R. M., Evans H. J. A hypothetical structural role for proline residues in the flanking segments of protein-protein interaction sites // Biochem. Biophys. Res. Commun. - 1995. - 212, N 3. P. 1115-1124.

5. Kini R. M., Evans H. J. A common structural feature enclosing interaction sites: Prediction of protein-protein interaction sites and development of potent bioactive peptides // Toxicon. - 1995. 33, N 11. - P. 1400-1401.

6. Kini R. M. Proline brackets and identification of potential functional sites in proteins: toxins to therapeutics // Toxicon. - 1998. - 36, N 11. P. 1659-1670.

7. Kini R. M., Evans H. J. Prediction of potential protein-protein interaction sites from amino acid sequence. Identification of a fibrin polymerization site // FEBS Lett. - 1996. - 385, N 1-2. - P. 81-86.

8. Cierniewski C. S., Budzynski A. Z. Involvement of the alpha chain in fibrin clot formation. Effect of monoclonal antibodies // Biochemistry. 1992. - 31, N 17. - P. 4248-4253. 
9. Lugovskoy E. V., Gritsenko P. G., Kapustianenko L. G., Kolesnikova I. N., Chernishov V. I., Komisarenko S. V. Functional role of Bbetachain N-terminal fragment in the fibrin polymerization process // FEBS J. - 2007. - 274, N 17. - P. 4540-4549.

10. Varetskaya T. V. Microheterogeneity of fibrinogen. Cryofibrinogen // Ukr. Biokhim. Zhurn. 1960. - 32, N 1. - P. 13-24. (In Ukrainian).

11. Lougovskoi E. V., Gogolinskaya G. K. Preparation of fibrin des-AA by thrombin // Ukr. Biokhim. Zhurn. - 1999. - 71, N 4. - P. 107-108. (In Russian).

12. Belitser V. A., Varetskaja T. V., Malneva G. V. Fibrinogen-fibrin interaction // Biochim. Biophys. Acta. - 1968. - 154, N 2. - P. 367-375.

13. Williams R. C. Band patterns seen by electron microscopy in ordered arrays of bovine and human fibrinogen and fibrin after negative staining // Proc. Natl. Acad. Sci. - 1983. - 80, N 6. - P. 1570-1573.
14. Gorkun O. V., Henschen-Edman A. H., Ping L. F., Lord S. T. Analysis of Aa251 Fibrinogen: The $\alpha \mathrm{C}$ Domain Has a Role in Polymerization, Albeit More Subtle Than Anticipated from the Analogous Proteolytic Fragment X // Biochemistry. - 1998. - 37, N 44. - P. 1543415441.

15. Urvant L. P., Makogonenko E. M., Pydura N. A., Kolesnikova I. N., Lugovskaya N. E., Lugovskoi E. V., Komisarenko S. V. Localization of epitope of fibrin specific monoclonal antibody I-3c within Bß118-134 fragment of human fibrin // Reports of the National Academy of Science of Ukraine. - 2013. - N 10. - P. 170-175. (In Ukrainian).

16. Jing P., Rudra J. S., Herr A. B., Collier J. H. Self-Assembling Peptide-Polymer Hydrogels Designed From the Coiled Coil Region of Fibrin // Biomacromolecules. - 2008. - 9, N 9. P. 2438-2446. 